\title{
Investigating Body Image Satisfaction among the Different Levels of Turkish Tennis Players as a Function of Gender
}

\section{Farklı Seviyelerde Tenis Oynayan Türk Tenisçilerinin Beden İmgelerinden Memnuniyet Düzeylerinin Cinsiyet Açısından Araştırılması}

\author{
Melih Öztop 1 iD https://orcid.org/0000-0002-4960-5567 \\ School of Physical Education and Sport, Gaziantep University, Gaziantep, Turkey
}

\author{
M. Settar Koçak iD https://orcid.org/0000-0002-8437-6181 \\ Department of Physical Education and Sports, Middle East Technical University, Ankara, Turkey \\ Received: January 15, 2019 \\ Accepted: March 24, 2019 \\ Online Published: March 31, 2019 \\ DOI: 10.30655/besad.2019.16 \\ https://doi.org/10.30655/besad.2019.16
}

\begin{abstract}
The study designed to investigate the role of playing tennis on Turkish university students' body image satisfaction as a function of gender. The present study also aimed to find out differences in body image satisfaction scores between different levels of tennis players. Data were obtained from 152 (77 male, 75 female) different levels of tennis players who are volunteer undergraduate university students from Middle East Technical University (METU) in Ankara, Turkey. In this study, data were gathered by administering two instruments, namely, Turkish version of Body Image Satisfaction Questionnaire and Demographic Information Form which was developed to collect personal information. A two-way ANOVA and 7X2 ANOVA were performed to analyze data. According to results there was no significant effect for gender on body image satisfaction scores. However, it can be stated that there was a significant difference between body image satisfaction scores and participants' tennis ability levels.
\end{abstract}

Keywords: Body image, tennis, gender

\footnotetext{
${ }^{1}$ Corresponding Author: Melih Öztop

Gaziantep Üniversitesi, Beden Eğitimi ve Spor Yüksekokulu, Üniversite Bulvarı, Şehitkamil, Gaziantep, TÜRKiYE. melihoztop@gmail.com
} 


\section{Öz}

Bu çalışma farklı seviyelerde tenis oynayan Türk üniversite ögrrencilerinin beden imgelerinden hoşnut olma düzeylerini cinsiyet açısından araştırmak için tasarlanmıştır. Bu çalışma ayrıca farklı düzeydeki tenis oyuncularının beden imgelerinden hoşnut olma durumlarının araştırılması amaçlanmıştır. Çalışmaya Ankara ilindeki Orta Doğu teknik Üniversitesi'nde okuyan 77 erkek 75 kadın olmak üzere toplam 152 üniversite öğrencsi gönüllü olarak katılmıştır. Araştırmanın verileri, araştırmacı tarafından geliştirilen kişisel bilgi formu ve türkçeye uyarlanan 'Berscheid, Walster ve Bohrnstedt Beden Imgesi Anketi' kullanılarak elde edilmiştir. Verilerin analizinde iki yönlü ve 7X2 ANOVA analizi kullanılmıştır. Araştırma sonuçları, öğrencilerin beden imgelerinden hoşnut olma düzeylerinin cinsiyet açısından anlamlı bir farklıık olmadığını belirtmektedir. Diğer taraftan katıımcıların tenis oynama seviyeleri ve beden imgelerinden hoşnut olma düzeyleri arasında anlamlı bir farkındalık bulunmaktadır.

Anahtar kelimeler: Beden imgesi, tenis, cinsiyet

\section{Introduction}

In this century, body image has a crucial role for both genders in society. Sport has been using as a tool to change his/her physical appearance (Toselli \& Spiga, 2017; Viviani, 2006). Body image has been perceived as a problematic issue for athletes, non-athletes, college students and adults. However, there is an inconsistency in the literature investigating a body image relationship with body mass index, self-esteem, body dissatisfaction, personal happiness, well-being, gender effect of physical appearance (Dost, 2006; Frederick, Bohrnstedt, Hatfield \& Berscheid, 2014; Hausenblas \& Downs, 2001; Keeton, Cash \& Brown, 1990; Koyuncu, Tok, Canpolat \& Catikkas, 2010; Lin \& Kulik, 2002; Stokes \& Frederick-Recascino, 2003; Viviani, 2006; Watkins, Christie \& Chally, 2008; Ince \& Dağlığlu, 2018). For instance, female exercisers and non-exercisers were investigated in terms of body image satisfaction with psychological components. According to results, exercises had a moderate effect on body image, self-esteem and social physique anxiety (Koyuncu et. al., 2010). Moreover, the womens' individual happiness had a strong relationship with their body image (Stokes \& Frederick-Recascino, 2003). Further, college students were satisfied with their good body shape (Toselli \& Spiga, 2017). Also body mass index and obesity had a significant relationship with negative body image (Watkins, Christie \& Chally, 2008). Koyuncu et. al. (2010) emphasized self-evaluation criteria by using social comparison theory (Festinger, 1954) that there were not objective evaluation standards.

There is a lack of study that investigating gender differences in active sport (Bozkurt et. al., 2006; Kleinwacher \& Raschka, 2009; Mandal, 2014). In contrast, athletes/non-athletes, adolescents and university students' perception toward the body image has been studied mostly (Keeton et. al., 1990; Koyuncu et. al., 2010; Watkins et. al., 2008; Zueck, Gastelum, Munoz, Benavides \& Peinado, 2015). The argument by Kleinswacher and Raschka (2009) that sport constitutional and anthropometrical of female and male tennis players who are playing in different levels indicates that male tennis players are heavier and taller than female tennis players. Yet, the vital question comes from that 'Which body frame characteristics are most noticeable when it comes to a tennis player' (p.215). Therefore, tennis sport requires many complex responsibilities in terms of physical performance. It is difficult to assess tennis players' body compositions. In general, women have fewer positive feelings with their body image than men (Cash, Morrow, Hrabosky \& Perry, 2004; Frederick et. al., 2014; Hausenblas \& Downs, 2001). Historically, body image mentioned as an outside view (Cash, 2004) that generally men were more satisfied than women (Silberstein, Striegel-Moore, Timko \& Rodin, 1988). 
Body image satisfaction has a vital role in individuals' quality of life, which is influenced by several physical, psychological and social factors. In the light of the literature the concept of body image is important to an understanding of physical, psychological and social development. Although there are lots of studies conducted to recognize body image satisfaction among the different categories, studies in sport branches of body image satisfaction are limited in Turkish culture. Turkish university students' body image were not be investigated in terms of tennis. More specifically, it is also known that change in body image as a result of physical exercise plays an important effect on body image satisfaction. Therefore, this study aims to investigate the role of playing tennis on Turkish university students' body image satisfaction as a function of gender. Additionally, the current study is to examine differences in body image satisfaction scores among discrete levels of tennis players.

\section{Method}

\section{Participants}

The subjects participating in this study were 152 students from different tennis levels enrolled in Middle East Technical University, an urban-state university, in the capital of Ankara, Turkey. All participants answered the questionnaire voluntarily. They were divided into seven levels according to their tennis ability. There were 77 male (49.3\%) and 75 female students (50.7\%), whose mean age was 22.82 years $(S . D=5.00)$.

\section{Instruments}

Body Image Satisfaction Questionnaire (BISQ) was used to measure participants' body image satisfaction (BIS) score. This questionnaire was primarily developed by Berscheid, Walster, and Bohrnstedt (1973). The questionnaire consists of 25 items and one more item added for males. It is composed of six sub scales, namely; general appearance of the body, face, body extremities, trunk, chest, and sexual organs. Each item is investigated the participants' satisfaction scores with his/her body parts throught 5-point scale, which (1) represented very dissatisfied and (5) very satisfied (5). Each item's score represents body image satisfaction. The Turkish variant of Body Image Questionnaire was adopted by Gokdoğan (1988). Total mean scores of scale are used for statistical calculations. In the present sample, internal reliability score was.94. A demographic information form was used to assess the volunteer participants' self-evaluations about themselves. It consists of age, gender, grade, height, weight, tennis levels, and reason of playing tennis.

\section{Procedure}

Researcher administered this study among the volunteer university students. Each participant spent approximately ten minutes to fill the questionnaire. Prior to the data collection process content of the research was explained by the researcher. Students' personality was not asked in the questionnaire to meet anonymity. Students completed surveys individually. The data were collected by the researcher around tennis courts during the spring tennis tournament.

\section{Result}

A 7X2 ANOVA was conducted to evaluate the effects of different tennis ability levels and gender on tennis players' body image satisfaction scores. The analyses indicated a significant main effect for tennis levels $F(6,126)=2.50, p=0.02$, partial $\left.\right|^{2=} .10 p<.05$. However, as can be seen by table 1 there is no 
significant effect for gender on body image satisfaction scores $F(1,126)=0.00, p=0.95$, partial $\left.\right|^{2=} .00$ $\mathrm{p}<.05$. Besides, the findings showed that there was no interaction between gender and tennis ability levels $F(5,126)=0.76, p=0.58$, partial $\left.\right|^{2=} .02 p<.05$.

Table 1. Two-Way ANOVA Results for the Effect of Tennis Ability Levels and Gender on Body Image Satisfaction

\begin{tabular}{cccccc}
\hline & $S S$ & $d f$ & $F$ & Sig. & $P^{2}$ \\
Gender & .61 & 1 & .00 & .96 & .00 \\
Level & 2996.23 & 6 & 2.50 & .03 & .11 \\
Gender * Level & 758.65 & 5 & .76 & .58 & .03 \\
Error & 25156.25 & 126 & & & \\
Total & 1304190.00 & 139 & & & \\
\hline
\end{tabular}

According to the result of the two-way ANOVA test, it can be stated that there was a significant difference between body image satisfaction scores of participants' tennis ability levels. According to results mean body image satisfaction scores were 95.56 for girls and 97.54 for boys. Among the participants who played tennis in first level were $M=85.47$ and $S . D=3.81$. Then, second level tennis players' $M=95.12$ (SD=3.17). Respectively in each levels, participants' mean and standard deviation scores, level 3: $M=95.17$ S.D=2.60; level 4: $M=95.05$ SD=2.30; level 5: $M=99.62$ SD=3.01; level 6: $M=102.50$ $\mathrm{SD}=5.76$; level 7: $M=110.40 \mathrm{SD}=6.31$. In addition, by analyzing table 2 the effects of tennis ability levels on participants' body image satisfaction scores were gradually in advance. Participants, who self-reported high tennis ability level also reported higher body image satisfaction.

Table 2. Mean and Standard Deviation of Participants' Tennis Level

\begin{tabular}{ccc}
\hline Level & $M$ & $S D$ \\
1 & 85.44 & 3.82 \\
2 & 95.12 & 3.18 \\
3 & 95.18 & 2.61 \\
4 & 95.05 & 2.31 \\
5 & 99.62 & 3.02 \\
6 & 102.50 & 5.77 \\
7 & 110.40 & 6.32 \\
\hline
\end{tabular}

In this study in order to test the possible differences between the different levels of tennis players as function of gender, a two-way ANOVA was calculated based on participants' body image satisfaction scores. The findings of the study were discussed in the light of related literature. Based on the results, we can say that levels of tennis ability had a significant effect on participants' body image satisfaction scores. However, there is no significant effect on participants' body image satisfaction scores in terms of gender.

\section{Discussion}


This study was designed to investigate the body image satisfaction scores among the different levels of Turkish tennis players as a function of gender. The results indicated that levels of tennis ability had a significant effect on participants' body image satisfaction scores. However, as can be seen by table 1 there is no significant effect for gender on body image satisfaction scores. Besides, the findings showed that there was no interaction between gender and tennis ability levels. In the literature, some studies about adolescents showed that males had more positive feelings with their body parts than females (Berscheid, Walster, \& Bohrnstedt, 1973; Çok, 1990; Viviani, 2006). Moreover, females wanted to be slender in social life (Viviani, 2006). Stoke and Frederick-Recascino (2003) indicated that there is a strong relationship between perception of body image and happiness for women. Further, Aşci et. al., (1997) found that male athletes were more satisfied about their body parts such as hair, ears, hands, abdomen, sport ability, abdomen then nonathletes. Similarly, male dancers had more positive feelings about their body parts than female dancers (Pekdağ \& Coşkun, 2010). On the other hand, except for male and female studies related to body image satisfaction that there were investigations about homosexuals and male to female transsexuals. According to findings, both homosexuals and male to female transsexuals had positive emotions about their body postures, height and legs by comparing with a control group (Bozkurt et. al., 2006).

The present research was consistent with investigation about well-being among university students. Although there were demographic differences in subjective well-being levels of the students in terms of physical appearance, there was no significant gender difference (Dost, 2006). Besides, Mandal (2014) compared two university students in terms of sport activity and body image. Although, male and female university students had a positive relationship with their physical appearance male students had more positive feelings for their body image than male students. In general, weight and physical appearance have a vital role in society (Frederick et. al., 2014; Koyuncu et. al., 2010). Furthermore, Koyuncu et. al. (2010) emphasized that self esteem, body image dissatisfaction; body fat ratio and physique anxiety were key components for females' psychological health. On the other hand, performance-level men tennis players had more positive physical characteristics than women. For instance, male and female tennis players who were played in different division were compared anthropometrically in Germany. According to results, male tennis players are heavier and taller than the female tennis players (Kleinwacher \& Raschka, 2009). Although there was a specific gender difference in Germany's sample, it may depend on men anatomy. In this study, findings showed that there was a significant correlation between body image satisfaction and participants' tennis levels. However, the present study does not support the conclusion of a clear gender-specific difference.

In this study, limitations should be considered. Participants evaluated their tennis ability level by their self-report. Also convenience sampling limited the generalizability of result of the study. Based on these limitations, the findings need to be replicated with high level tennis players among university students or professional Turkish tennis players to validate the findings of this study. Different sport branches should be taken into consideration with body image satisfaction.Regardless of aforementioned limitations, this study consolidated the existing literature on body image satisfaction with university students who are playing tennis in different levels. There is a lack of studies investigating predictors of body image satisfaction among the tennis players, and it would be useful to establish frameworks that can guide future research. It was thought that playing tennis in high level would impress the university students' body image satisfactions. Without thinking gender differences both male and female university tennis players may benefit from advantage of tennis sport. The present study highlighted the importance of body image satisfaction by using tennis among the 
university tennis players. From these findings, it seems that tennis may be used to promote body image perceptions. Specifically, there was a significant correlation between tennis and body image.

\section{References}

Asci, F. H., Gokmen H., Tiryaki, G., \& Asci, A. (1997). Self-concept and body image of Turkish high school male athletes and nonathletes. Adolescence, 32(128), 959.

Berscheid, E., Walster, E., \& Bohrnstedt, G. (1973). The happy American body: A survey report. Psychology Today, 119-131.

Bozkurt, A., Isikli, H., Demir, F., Ozmenler, K. N., Gulcat, Z., Karlidere, T., \& Aydin, H. (2006). Body image and personality traits of male-to-female transsexuals and homosexuals. Social Behavior and Personality: an international journal, 34(8): 927-938.

Cash, T. F. (2004). Body image: Past, present, and future. Body Image, 1, 1-5.

Cash, T. F., Morrow, J.A., Hrabosky, J. I., \& Perry A. A. (2004). How has body image changed? A cross-sectional investigation of college women and men from 1983 to 2001. Journal of Consulting and Clinical Psychology, 72(6), 1081.

Çok, F. (1990). Body image satisfaction in Turkish adolescents. Adolescence, 25(98), 409.

Dost, M. T. (2006). Subjective well-being among university students. Hacettepe University Journal of Education, 31(31), 188-197.

Festinger, L. (1954). A theory of social comparison processes. Human relations, 7(2), 117-140.

Frederick, D., Bohrnstedt, G. W., Hatfield, E., \& Berscheid, E. (2014). Factor structure and validity of the Body Parts Satisfaction Scale: Results from the 1972 Psychology Today survey. Psihologijske teme, 23(2), 223-242.

Gökdoğan, F. (1988). Orta öğretime devam eden ergenlerde beden imgesinden hoşnut olma düzeyi. Unpublished master's thesis, Ankara University. Ankara, Turkey.

Hausenblas, H. A., \& Downs, D. S. (2001). Comparison of body image between athletes and nonathletes: A meta-analytic review. Journal of Applied Sport Psychology, 13(3): 323-339.

Ince T., \& Dağlığlu, O. (2018). The effect of plyrometric training program on sportive performance parametres in young soccer players. Turkish Journal of Sport and Exercise, 20(3): 184-190.

Keeton, W. P., Cash, T. F., \& Brown, T. A. (1990). Body image or body images?: Comparative, multidimensional assessment among college students. Journal of Personality Assessment, 54(1-2), 213-230.

Kleinwächter, R., \& Raschka, C. (2009). Anthropometrical and sport-constitutional comparison of male and female tennis players at different performance levels. Papers on Anthropology XVIII, 214-226.

Koyuncu, M., Tok, S., Canpolat, A. M., \& Catikkas, F. (2010). Body image satisfaction and dissatisfaction, social physique anxiety, self-esteem, and body fat ratio in female exercisers and nonexercisers. Social Behavior and Personality: an international journal, 38(4), 561-570.

Lin, L.F., \& Kulik, J.A. (2002). Social comparison and women's body satisfaction. Basic and Applied Social Psychology, 24(2), 115-123.

Mandal, E. (2014). Sport Activity and Body Image of Men and Women. In: Physical Activity in Science and Practice, Flemr, L., Nemec, J., \& Kudlackova, K., eds. Prague: Charles University, 71-82.

Pekdağ, F., \& Coşkun, F. (2010). Social physique anxiety and body image satisfaction levels of collegian dancers. Pamukkale Spor Bilimleri Dergisi, 1(2), 17-24.

Silberstein, L.R., Striegel-Moore, R. H., Timko, C., \& Rodin, J. (1988). Behavioral and psychological implications of body dissatisfaction: Do men and women differ?. Sex Roles, 19(3-4), 219-232. 
Stokes, R., \& Frederick-Recascino C. (2003). Women's perceived body image: Relations with personal happiness. Journal of Women and Aging, 15(1), 17-29.

Toselli, S., \& Spiga, F. (2017). Sport practice, physical structure, and body image among university students. Journal of Eating Disorders, 5(1): 31.

Viviani, F. (2006). Some aspects of the body image and self-perception in adolescents. Paper Anthropology, 15, 302-309.

Watkins, J.A., Christie, C., \& Chally, P. (2008). Relationship between body image and body mass index in college men. Journal of American College Health, 57(1), 95-100.

Zueck, M. D. C., Gastelum, G., Munoz, F., Benavides, V., \& Peinado, J. E. (2015). Physical self-concept of mexican athlete and non-athlete teenagers. European Scientific Journal, ESJ, 11(3): 379-385. 